\title{
Development of the Requiem Genre as a Reflection of Philosophical and Social Ideas About Death
}

\author{
Andrey Yu. Seibert* \\ Dmitri Hvorostovsky Krasnoyarsk State Academy of Arts \\ Krasnoyarsk, Russian Federation
}

Received 02.05.2020, received in revised form 28.05.2020, accepted 05.06.2020

\begin{abstract}
The article deals with the Requiem genre and its evolution in the context of a philosophical worldview through various historical periods of human development. The basis for this is the periodization proposed by V.V. Mineev, which reflects different attitudes to death in the process of evolution of philosophical and scientific thought. Views of the public consciousness concerning the issues of death resonate not only with philosophical reasoning and scientific works, but also with works of art. In the field of music, this is particularly evident in the genre of Requiem, which produces immediate response to social change. The author traces the transformation of ideas about death from superstitious - fantastic nature to medical justification of death, its treatment and prevention.

The Requiem originated within the walls of the Catholic Church as a cult genre, capable of instilling religious fear in parishioners. Over time, it has freed itself from prejudice and gradually accumulated not only the memories of a particular deceased person who, but also the recollections about all mankind. The latter trait manifests itself in a departure from the Latin text and images of the Last Judgment, as well as in introducing secular texts into the spiritual genre.
\end{abstract}

Keywords: Requiem, church genre, religious music, philosophy, death.

Research area: musical art.

Citation: Seibert, A.Yu. (2020). Development of the Requiem genre as a reflection of philosophical and social ideas about death. J. Sib. Fed. Univ. Humanit. Soc. Sci., 13(6), 945-950. DOI: 10.17516/19971370-0617.

(C) Siberian Federal University. All rights reserved

* Corresponding author E-mail address: postprintpack@gmail.com ORCID: 000-0002-3906-5632 
The history of music is inextricably linked to the history of human development. For thousands of years, music has accompanied everyday life, and so it is quite natural that there emerged such genres that reflect the most important events of the earthly path. It is no coincidence that L. Mazel and V. Tsuckerman define the genre as "such kinds and types of musical works, historically formed in connection with various social functions of music (in particular, its functions of accompanying routine affairs and social-applied functions) based on certain types of its content, its essential purposes, conditions of its performance and perception" (Mazel, Tsuckerman, 1967: 22).

In this respect, the genre of Requiem seems to be exceptionally specific, for it corresponds to the moment when a human passes to another stage: from life - to death, from reality - to the world beyond, from suffering - to eternal bliss (or vice versa, from earthly pleasures - to everlasting torment). And the bifurcation point separating them is death.

The idea of death, with which the appearance of the Requiem is associated, has been changing over time. Consequently, the genre itself has predictably changed. This article will attempt to highlight some of the processes of development of the Requiem, which followed changes in the social, philosophical, moral-ethical and aesthetic views of society

The name of the genre, as we know, comes from the first words of the Catholic prayer Requiem aternam dona eis Domine (Eternal rest grant unto them, $O$ Lord). Accordingly, Requiem is a mass of mourning which is associated with the image of death. Doctor of Philosophy, Professor V.V. Mineev in his book "Philosophy of Death and Dying" considers the history of human development in connection with death and proposes his own periodization, consisting of five stages. Let us take it as a basis, since it is, in our opinion, the most indicative and objective at the present time of all existing concepts. Let us specify in advance that V.V. Mineev in his periodization relies not on historical periods of cultural development (antiquity, Middle Ages, Renaissance, etc.), but on types of thinking that sometimes go against the usual chronological boundaries of epochs.
The first type is characterized by the "harmony of life and death of the living and dead" (Mineev, 2003: 79). This is due to the fact that death was perceived as an ordinary, inevitable and not instilling fear phenomenon. This perception of death was characteristic of the ancient man who did not treat death as a personal tragedy. There was a perception that the bodies of the deceased once entrusted to the care of the Church would sleep peacefully in anticipation of the Second Coming. It is not accidental that such idylls were preserved until the end of the $19^{\text {th }}$ century.

The second type dates back to the $12^{\text {th }}$ century and was the dominating one until the $18^{\text {th }}$ century. In the light of purpose of this article, this period is of particular interest, because the $13^{\text {th }}$ century marked the incipience of the canonical text of the Requiem and since that the structure of the genre has been crystallizing to correspond to the church service. Social psychology of the Middle Ages was characterized by contrasting, sometimes opposite states that the individual experienced: "The constituent of medieval sensitivity was the indivisibility of the intellectual and emotional spheres. Medieval people, as historical sources depict them, appear extremely sensitive" (Shkuratov, 1994: 156). Intense impressibility, based on ancient prejudices, freely lapsed into pathological manifestations of fear. "Medieval civilization was formed in the atmosphere of physical fear of man against the constant threat from the surrounding world. Truly, there was no place or moment in their life when they would feel safe. People of that epoch were constantly in a state of heightened excitability, easily debouching into hysteria" (Barg, 1987: 140-141). One of the main components of human consciousness was fear, and the whole Christian worldview venerated importance of fear of the power and might of the Creator, of the vengeance of the Almighty, of His will and of the Last Judgment.

The image of the Last Judgment is among the most ubiquitous themes of medieval art. The most frequently the idea of the Last Judgment was reflected in a huge number of paintings on this theme created in this period. Mandatory episodes of the wall painting of Catholic 
churches were those dedicated to the apocalypse.

The emphasis on eschatological themes, the detailed display of the Day of Lord determined the relationship between the church and man. The church dictated the moral imperatives which a person had to obey. At the end of the $13^{\text {th }}$ century, Raymundus Lullius wrote: "There is no need to be afraid of death. It is impossible to foreshadow when it will come, it is impossible to avoid it, it is necessary to care only for the salvation of the soul, for the fearful is not the death of the body, but the death of the soul". In this connection, there comes to the fore the idea of punishment for mortal sins, which is most clearly embodied in the work by $\mathrm{H}$. Bosch The Seven Deadly Sins (1475-1480). It is indicative that in the central part of the canvas there is an inscription Cave cave d[omi]n[u]s videt ("Beware, Beware, The Lord Sees").

In the studied historical period people were constantly and literally surrounded by death. The evidence is the fact that cemeteries were situated in residential areas, and it was not until 1763 that it was decided to relocate them outside the city. In addition, cholera and plague epidemics were rampant in Europe, they repeated every 10-12 years due to the low level of medicine, which gave the church a reason to consider any disease as punishment for mortal sins. Thanatological themes and medieval ideas of people were realized in another genre that originated at the time: Dansemacabre, i.e. the dance of death. Without describing it in detail in the present article, let me mention that at first it was a series of paintings. The very first examples depicted Death, leading a string of dead, in which people alternated with skeletons.

This kind of mentality is also exemplified in the Requiem. When the text of the mass of mourning is being compiled, the central episode is Dies irae, which presents events of the Last Judgment. In textual terms, this is the largest part (the entire Requiem contains 89 lines, Dies irae - 57 lines). Musically, this is reestablished by the Gregorian chorale passage in the sequence. It is known that the first Requiem belongs to Guillaume Dufay, but the author of the first specimen in this genre, which survived to us, is one by Josquin Depré (c. 1470). Other famous Requiems are the masses of Pierre de La Rue, Giovanni Palestrina and Orlando Lasso. It is not possible to highlight in detail the features of these works because of the lack of score and the low popularity of the works.

The third historical type of attitude to death originated in the $14^{\text {th }}$ century and reached its peak during the Enlightenment. In this period, death was regarded as the result of biological aging of man. "High Realism" achieved the alienation of man from death, treating it as a social act and no more. Reason and rational attitude to all phenomena emerged in prominence following the appearance and active development of atheistic tendencies. This brought disharmony into the balance between life and death that had existed in medieval aesthetics and theology. Until the $18^{\text {th }}$ century, man had not sought to understand and cognize death by scientific methods. Then it became important to explain all processes, to find logic in everything that is impossible with a priori respect to death. Death became "wild" - incomprehensible, unknowable, inexplicable. Attempts to study death empirically are shown in one of Rembrandt's paintings The Anatomy Lesson of Dr. Nicholaes Tulp, where a group of students attends the autopsy of the corpse.

We may find interesting observations in T. Mordovtseva's book "The Idea of Death in Cultural-Philosophical Retrospective": "Passion for anatomy at that time is a fashionable occupation not only for male specialists (doctors and lawyers), but also for curious women. Anatomical drawing may become a nice gift for a lover or a visual aid for a student. And a rich man, not without interest in the different phenomena of nature, could afford to have an anatomical study and do the autopsy as a hobby in the pauses between lunch and evening meals. Grave digging for a while even becomes a profitable business, 'fresh' material has a special price and is usually sold without any delay" (Mordovtseva, 2001: 76).

The previously dominant, lasting for centuries contempt for the lifeless body is dispersed by itself under the influence of reason and will. Man seeks to understand lethality in order to anticipate, and nothing can pre- 
vent him from doing so. It is no coincidence that M. Foucault in his work "The Birth of the Clinic" compares life, illness and death, coming to this triad in the course of theoretical and metaphysical reasoning. Grasping the essence of the disease predetermines its treatment and prevention. Death is seen as the same disease, a temporary illness for which there should be a cure. The appearance of death can be opposed in the same way as the birth can be prevented, because death is a process, rather than a moment.

While in the public consciousness the breathless body still retains signs of the influence of the other world on the mundane one (e.g., zombies, vampires), in the academic circles the remnants are "dishonoured" with a lancet and a surgical knife and turned into a doctor's handy material, like clay for a potter or marble for a sculptor. The corpse loses its cover of mystery, and after this death itself transcends the boundary of the material. Thus, in human consciousness, death descends to the bottom in the hierarchy of distorted perceptions and false ideas, with the dead body occupying the entire space of physical reality. Therefore, "from the anatomical cabinet, Death is gradually heading towards art and literature" (Mordovtseva, 2001: 78).

Requiem in this period is characterized by the penetration of secular features, in particular, the introduction of traditions, vocal forms and methods of development peculiar for theatrical art. The desire to make the Requiem understandable and accessible to the bourgeois public led to the appearance of the German Requiems by M. Praetorious (year of its creation is unknown) and H. Schütz (1636). The secularization of the genre and a different view of death resulted in the appearance of major versions such as the Requiems by $\mathrm{H}$. Biber and J.A. Hasse.

In the specified by V.V. Mineev period, which started in the second half of the $18^{\text {th }}$ century and ended with the end of the $19^{\text {th }}$ century, one can also include a romantic Requiem. At this time, the role of family and kinship ties was increasing. Therefore, the death of a loved one was experienced as a personal tragedy, a great loss. It is not by chance that in 1791 Requiem by W.A. Mozart appeared. Mozart's Requiem is fundamentally pre-Romantic and it became a model for a new type of mourning mass where the emotional aspect is ingrained into the musical content. In the $19^{\text {th }}$ century, these tendencies were exacerbated by those characteristic features that distinguish the Romantic era from other artistic phenomena. The state of experience, the tragedy of human life; accentuated in the aesthetics of romanticism, is further intensified in mourning mass. In addition, the Requiem epitomizes a number of philosophical and aesthetic endeavors characteristic of the $19^{\text {th }}$ century.

In the line of romantic ideas, the Requiem personified a craving for national concepts which is most vividly represented in the German tradition. The German Requiem by I. Brahms is symbolic in this respect, since its text instead of being a translation from Latin into German was made by the composer himself on the basis of the biblical source. The tendency to synthesize the arts, which constituted the era of Romanticism, manifested itself in the introduction of theatrical traits in the Requiems by $\mathrm{H}$. Berlioz and G. Verdi. On the other hand, the aspiration towards intimacy and the chamber character of the "ulterior" bearing one's grief (the expression of M.P. Musorgsky) took its shape in the Requiem of C. Saint-Saëns. An interesting example here is F. Liszt's Requiem written for male chorus as the composer created the work when he served as the Abbot and thus was focused on the monastic chorus.

The fifth type of thinking, according to periodization offered by V.V. Mineev, formed at the sunset of the $19^{\text {th }}$ century. Against the background of the powerful development of the scientific knowledge and many discoveries in various fields, a person was losing faith in the higher forces, the Higher Reason. In the $20^{\text {th }}$ century people rethought themselves as the creators of the life. A person is enkindled by a desire to own the whole world, which reinforces the wish to explore the space and ocean depths. The idea of educating a man-god, who would exert power not only over life but also over death, was developing in this century. A separate branch of science appears - thanatology (the science of death). "The idea of death 
is interpreted in the context of cultural crisis, degradation of customary stereotypes of person's thinking towards depersonalization and desubjectivation" (Mordovtseva, 2001: 85). "The thought of death ousting clogs the mind. The dream of killing death is transformed into the practice of killing people" (Mineev, 2003: 80 ), which is expressed in total violence and numerous wars.

The tendencies of fusion of secular and religious principles continued to develop in music art in this period. In the Requiem this is materialized not only in the preservation of Latin text, but also in the usage of secular texts of poets and writers. These are Requiems for the memory of victims of the Revolution, of the Great Patriotic War and alike, B. Britten's The War Requiem (1962), in which the Latin text is interspersed with poems by the English poet W. Owen; Requiem dedicated to those who died in the fight against fascism by D. Kabalevsky (1973) who used the poem of R. Rozhdestvensky; Requiem by E. Denisov (1980) who used the verse of F. Tanzler and Latin texts; The Fire Requiem by N. Lens (2003) who used the libretto of the Belgian writer and diplomat Hermann Portocarero, etc. It should be noted here that despite all the variety of author's original readings of the genre, the stimulus to create a requiem (to pay homage to the memory of humanity, the memory of a particular person) remains the same.

So, European culture has undergone several revolutionary changes in public and scientific consciousness. The attitude to death has also changed. At the beginning, there was an emotional rapture of life, the sensual freedom of which obscured the concurrent fear of postmortem punishment. The urge to feel the fullness of being made a person look for ways to avoid suffering, and the consequent disease and death. As time wore on, death became controllable and manageable due to inexhaustible possibilities of mind, now it organically fits into the natural life cycle of matter and nature, losing its incomprehensible essence. From now on, death does no longer cause awe, as nowadays it can be studied. "Having been a secret enemy, it is becoming a blatant opponent of man. With the development of medicine religious fear finally gives way to scientific optimism, and now the subject of faith is not a transcendental essence, but the human mind. People gain faith in the ability to control everything that opposes their authority. Thanks to the emancipation of the mind, previously forbidden sensual experiences are also freed. Willful control exercised by religious prohibitions and intimidation of punishment are being removed" (Mordovtseva, 2001: 83).

All stages in the evolution of human consciousness are somehow depicted in the Requiem. Dating back to the $13^{\text {th }}$ century, this genre still undergoes some changes and, like a symphony, it is able to mirror the worldview of the era, bringing to the foreground the problems of death seen in philosophical, spiritual and moral terms. Having lost the connection with the church ritual character, it gradually rose to the level of conceptual genre, capable of embodying generalized philosophical ideas.

\section{References}

Barg, M.A. (1987). Epokhi i idei. Stanovlenie istorizma [Eras and ideas. The formation of historicism]. Moscow, Mysl', 350 p.

Mazel, L.A., Tsuckerman, V.A. (1967). Analiz muzykal'nykh proizvedenii [Analysis of musical works]. Moscow, Muzyka, 752 p.

Mineev, V.V. (2003). Filosofiia smerti i umiraniia [The philosophy of death and dying]. Krasnoyarsk, Krasnoyarsk State Pedagogical University, 252 p.

Mordovtseva, T.V. (2001). Ideia smerti v kul'turfilosofskoi retrospektive [The idea of death in a cultural philosophical retrospective]. Taganrog, Taganrog Institute of Management and Economics, $120 \mathrm{p}$.

Shkuratov, V. (1994). Istoricheskaia psikhologiia [Historical Psychology]. Rostov-na-Donu, "Gorod N", 288 p. 


\title{
Развитие жанра реквиема как отражение философско-социальных представлений о смерти
}

\author{
A.Ю. Сейберт \\ Сибирский государственный институт искусств \\ имени Дмитрия Хворостовского \\ Российская Федерачия, Красноярск
}

Аннотация. В статье рассматриваются жанр реквиема и его эволюция в контексте философского мировоззрения в различные исторические периоды развития человечества. За основу взята периодизация, предложенная В.В. Минеевым, которая отражает разное отношение к смерти в процессе эволюции философской и научной мысли. Взгляды общественного сознания относительно вопросов смерти находят отклик не только в философских рассуждениях, научных трудах, но и в произведениях искусств. В сфере музыки особенно ярко это проявляется в жанре реквиема, способном остро реагировать на социальные изменения. Автором прослеживается трансформация представлений о смерти от суеверий мистикофантастического характера до медицинского обоснования появления смерти, ее лечения и профилактики.

Реквием зародился в стенах католического храма как культовый жанр, способный вселять в прихожан религиозный страх. С течением времени он освобождается от предрассудков и постепенно аккумулирует в себе не только память об одном человеке, но и память обо всем человечестве. Последнее проявляется в отходе от латинского текста, изображения картин Страшного суда, а также в привлечении светских текстов в духовный жанр.

Ключевые слова: реквием, духовный жанр, культовая музыка, философия, смерть.

Научная специальность: 17.00.02 - музыкальное искусство. 